\title{
FORMS OF INSTRUMENTS IN COLLECTIVE MEMORY: THE EXAMPLE OF KEMENÇE
}

\author{
Gözde Çolakoğlu Sarı \\ Assoc. Prof. Dr., Istanbul Technical University, Turkey, gozde.colakoglu@gmail.com
}

\begin{abstract}
Instruments play a significant role in establishing peoples' music at cultural memory and shapes of these instruments hold an important place in cultural memory. For instance, Eastern Black Sea Region is associated with kemençe and Aegean region with sipsi. The immediate vision that comes to memory is that of a tar when Azerbaijan is mentioned, or it is bagpipes for Scotland. When we discuss armudî kemençe (pear shaped kemençe), one of our instruments, which make good examples for our subject, we see that the same form and structure is found in the musical memories of neighbouring geographical regions, under various different names. Instruments, which are referred to as lyra in Greece and Aegean Islands, as lyrica in Croatia, as gadulka in Bulgaria, in Turkey, as kemençe in art music circles, and as tırnak kemane in Kastamonu and its environs, and which have established themselves under these names at memories in their respective territories, have similar traits in terms of performance and morphological features, and are evidential examples of collective music memory. But individuals living in these societies use the name of instrument, what they call in their region while talking about the music instrument. In this paper, forms of instruments, which have established themselves at collective memory, is analyzed through the example of kemençe, the variations of the instrument found in the Balkans and in Anatolia, and their place in collective memories will be discussed in comparison.
\end{abstract}

Keywords: Musical Instruments, Kemençe, Collective Memory.

\section{INTRODUCTION}

Language, tradition and customs which were handed down from generation to generation is important elements frozen in the memory of societies. It is possible to enlarge these elements in several fields. Music genres, dance types and composers which gained the title of being 'traditional' are at the back of mind of society when considered in respect to musical. Musical instruments which are defined as objects used for making music and sound among these objects have an important place. Besides the essential existence of musical instruments in community life, slowness of tone and variance of types is directly proportional with collective memory. It is witnessed the type variance of traditional musical instruments is proportional with variance of society which spreads centuries. For that reason after musical instruments are placed in the memories of society; it becomes impossible to erase this and society stubborn about the image which have been received into the memory. 
Musical instruments reserve an important place in the means of settling memories of societies and these musical instruments are saved to memory with their types. For example Eastern Black Sea region identified with kemençe, Aegean region identified with sipsi. While the first image of memory was tar when Azerbaijan referred, it becomes gaydalbagpipe when Scotland is referred. When bağlama and its family were referred first thought was its classic type. In spite of bağlama which was produced from the mulberry tree became leaf tree technique and change of its raw material there is no change on its form. Even a manufacturer in Izmir is known to produce the nut of bağlama by aluminium. This situation is the loyalty of social memory. Classic type of music instrument is based on namely the main form of instrument, even for the 'frame' instruments which were produced by way of electronic microphones (e.g. frame violin, frame ud). In fact the shape of music instrument in frame form is not important it is possible to select any shape.

\section{THE EXAMPLES OF PEAR-SHAPED KEMENCE AND COLLECTIVE MEMORY}

When example of pear shaped kemençe which is played with nail touch, it is seen that the same type and structure including small differences called in different names for each several geographical regions. Instruments settled in the memories of society with different names such as lyra in Greek and Aegean islands, gadulka in Bulgaria, lijerica in Croatia, kemençe in Turkey in traditional Turkish music, tırnak kemane around the Kastamonu and Fethiye are the significant examples of social music memory. But individuals living in these societies use the name of instrument, what they call in their region while talking about the music instrument.

\subsection{Rebec}

When start to track the pear shaped stringed instruments in historically and geographically first music instrument met us is rebec which was one of the first historical musical instrument. It symbolizes the Middle Ages according to German musicology organolog Curt Sachs'a (1881-1959) in classification of instruments (Sachs, 1992, p. 278).

It is knows the name of rebec comes from rebebe, reberbe, rebesbe from French; and ribibe, ribible, rubebe ${ }^{1}$, rubible and rybybe from English as terminologically and this term mentions stringed instruments. Tinctoris (1435-1511) who was the Franco - Flaming composer of renaissance period and music theorist mentioned that name of rebec was used firstly in France between 1280-1300 in his work named De inventione et usu musicae and several variances of this instrument were played in Byzantine Empire and Europe by the name of lyra dicta (Downie, 1981, p. 63). Usage of lyra which means an instrument played with string name in $10^{\text {th }}$ century by Persian İbn Kurdadhbih dedicated to Abbasid khalif Al-mutemid (870-892) in an article about Byzantine instruments and indicate of lyra among the Byzantine instruments is an important determination (Farmer, 1925, p. 299). Reason of terminological change of this variation is the nonexistence of rebec word in Arab and Latin languages in $12^{\text {th }}$ centuries (Baines, 1992, p. 279-280). So while the instrument was being played with the name of lyra in Byzantine courts it was named rebec after a short while of its entrance to Europe.

Mary Remnant who is specialist on Middle Age instruments and examined the instrument figures of that period with details, mentions Middle Age sculptors generally use the figure of angle which was symbolized with instruments in church (Remnant, 1968-1969, p. 26). Rebec exists in these representative figures which were seen on images and decoration of wall, ceiling and large fixed surfaces. When the historical documents are evaluated, it is understood the oldest logs extends to year of 1000. Instrument is one of the significant elements of religious and non-religious ceremonies which were organized in Byzantine courts on that period.

Rebec attracts the attention on several images about Commander, Prophet and second Jewish king Davud (King David) who lived in Sinai (desert) and played an important role during the entrance of Israeli's to Jerusalem. Also rebec was used in chant books, engravings which made on church walls and daily used materials as a sign. In this context the reality of evaluating instrument in respect to semiology theory which assesses their systematic processes occurs (Saussure, 1959-1916, p. 16). Founder of this theory Swiss philologist Saussure (1857-1913) and American pragmatist philosopher Charles Pierce (1839-1914) notified the importance of cause and effect relation which were symbolized by organic link or connection (İzbul, 1980 , p. 60). Accordingly rebec was an important semiologic element in Middle Age and the power which gave this qualification to it was the usage of as a musical instrument in Byzantine and Europe court (Figure 1).

\footnotetext{
${ }^{1}$ This term was used for Jew's harp, too.
} 


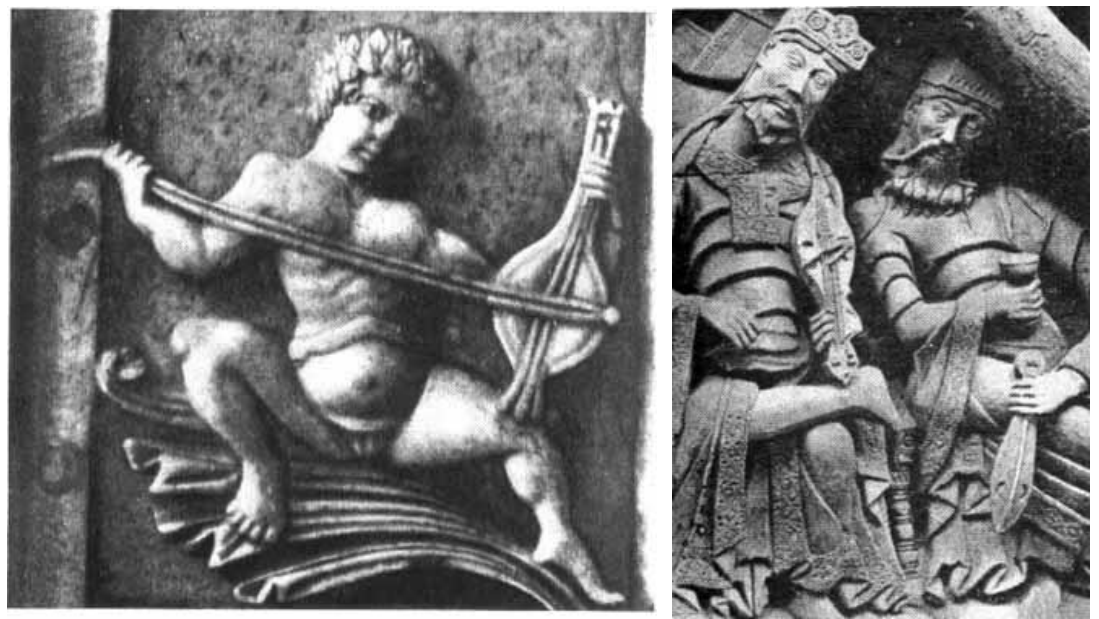

Fig 1. An Ivory Case from Byzantine Era (Museo Nazionale, Floransa, 26) and The Relief of Kind David from Vienna Cathedral from France from the 12th Century (Paul Butler, Private Collection)

\subsection{Lyra}

Lyra was another instrument used as a semiologic element after rebec. Even it was mentioned there were several instruments played by nail touch to stringers in per shaped form as usage of kemençe name in the title of notice, someone who plays kemençe uses Greek kemençe for lyra saw in Greek. Term which is used for kemençe of Turkish music is politiki lyra namely Istanbul lyra.

It mentioned above that usage of lyra which means an instrument played with string name in $10^{\text {th }}$ century by Persian İbn Kurdadhbih dedicated to Abbasid Khalif Al-mutemid (870-892) in an article about Byzantine instruments and indicate of lyra among the Byzantine instruments is an important determination (Farmer, 1925, p.299). From this writing up to today, many Byzantine and post-Byzantine iconographic and literate sources witnessed the existence of lyra instrument and pear shaped stringed instrument were used under the name of lyra dicta in Byzantine Istanbul before called in Europe as rebec.

Lyra is played in Crete, Kasos and Karpathos islands of Greek, and Thrace and Macedonia regions today. Also it is known that lyra is used in Italy (southern Italy-Calabria) which dominated in the Dodecanese islands for 36 years including Kasos and Karpathos islands and Croatia (Adriatic - Dubrovnik), as the mentioned regions investigated it is determined that the functionality and identity of lyra changes.

This change rebounds the name of instrument too and lyra is called with the name of period played. In Cretan it is called lyra kritiki / Cretan lyra, Halki island Halkitiki lyra / lyra of Halkitiki, Kasos island Kassiotiki lyra / lyra of Kasos, Ikaria island Ikariyotiki lyra or lyra tis Ikariyas / lyra of Ikaria, Drama Dramini lyra / lyra of Drama, Tray Thrakyotiki lyra / Thracian lyra, Karpathos island Karpathiyotiki lyra / lyra of Carpatos, Bulgaria Vulğariki lyra (gadulka), Southern Italy lyra tis Notias Italiyas / Calabrian Lyra, Croatia and Adriatic beaches lyritsa (Yugoslaviki lyra). Also it is know the kemençe played in İstanbul is called Politiki lyra namely Polis lyra. Polis means city here and derived from the name of Constantinople which means city of Byzantine imperator Constantine. These kinds of examples prove the place of instrument in memory of societies (Figure 2). 


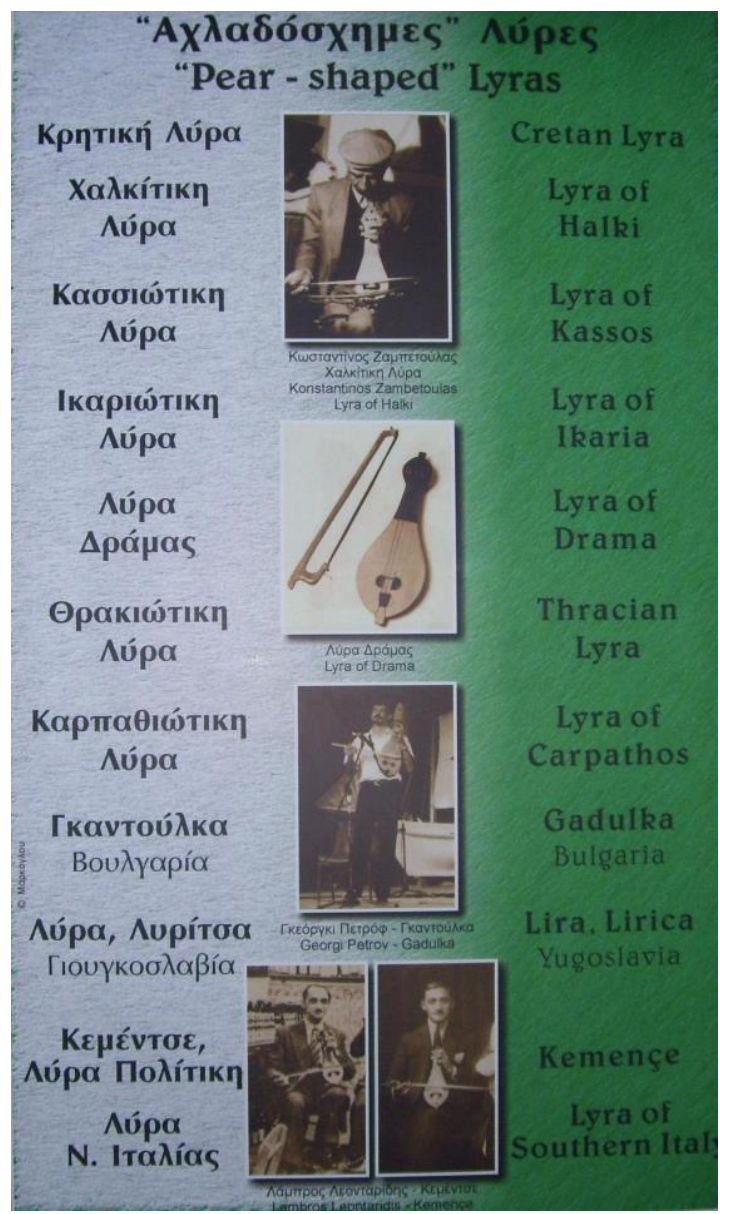

Fig 2a. A poster from Labyrinth Musical Museum in Crete
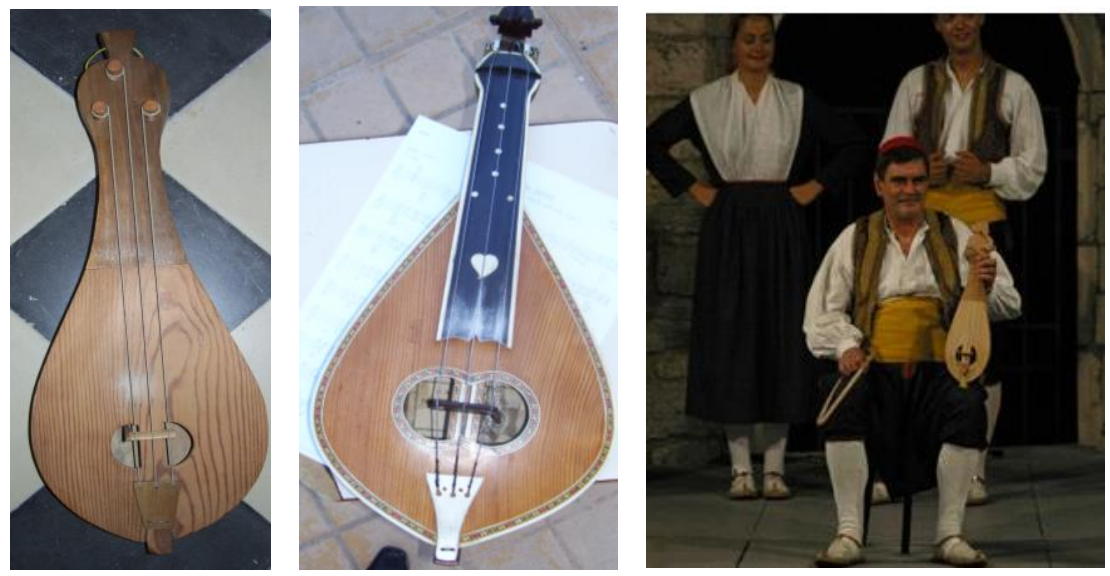

Fig 2b. Traditional Lyra and Cretan Lyra from Labyrinth Musical Museum in Crete and Lijerica (Joseph Divic, Private Collection)

Semiologic characteristic of rebec mentioned above is valid for symbol of social life of islands in greed also for lyra which was played in Thessaloniki and Drama cities by local residents. Instrument continues its existence as a semiologic element which emphasizes the soul of traditional Cretan colloquially and in tourism sector (Figure 3). 

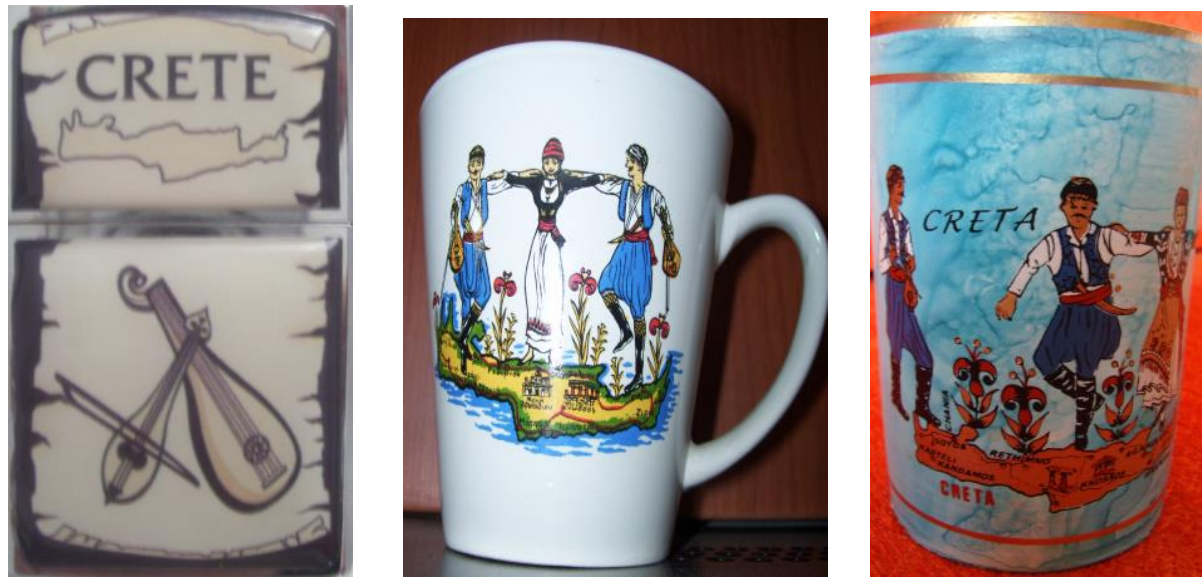

Fig 3. A lighter and cups bought from Dedalu Street in Iraklion in Crete from a touristic shop in July 2007.

\subsection{Kemençe}

Kemençe and tırnak kemane, which are the members of pear shaped instruments family, and was at the back of society mind of Kastamonu and around in $18^{\text {th }}$ century as instruments used for accompanying to dance. First documents about kemençe were the writing work of Hızır Ağa rebab, keman, keman-ı kıptî and ıkığ, Tevhim ül-makamat fi tevlid en nagamat (Hızır Ağa, 1749, 21b, 28a) and travel books of some itinerants who came to visit country. Calling kemençe as lyra in these travel books shows the stubborn of their image and type what was registered in their memory. Historical documents proves that kemençe was an instrument which was played as 'kaba saz' in coffeehouses, pothouses and used for fun music in 'köçekçe', 'tavşanca' and 'Rumelia musics' in the end of $18^{\text {th }}$ century and second half of $19^{\text {th }}$ century. Kemençe and lavta is played together at an old Istanbul pothouse in embroidery of Enderuni Fazıl work of Hubânname and Zenannâme, either a song was being sung or a rabbit plays (Figure 4).

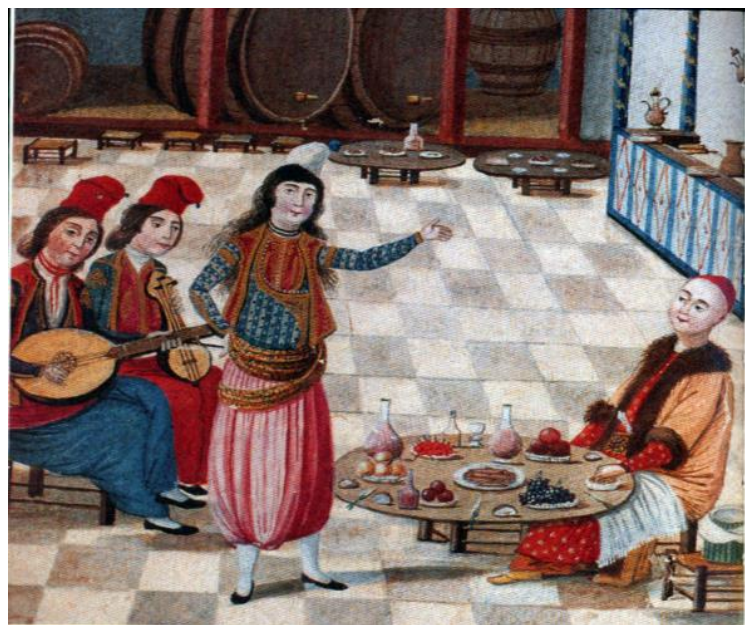

Fig 4. 'Kaba Saz Ensemble' A picture from Hubanname ve Zenanname written by

\section{Enderûnî Fazıl}

Kemençe was settled in memory of society in respect to the technique of playing with nail touch and pear shape which was not seen before in Turkish music. Settling in fun music was realized by famous kemençe performers Vasilaki and Tanbur Cemil Bey.

\subsection{Kemane}

Tırnak kemane which is played by nail touch to stringers and pear shaped; is performed in Şenpazar, Kastamonu, Azdayav, Inebolu, Safranbolu and Cide center also neighbor cities Zonguldak, Bartın and Karabük. Is was determined that the instrument was played in Western Mediterranean and especially Teke region where migratory life is common besides the performing of Western Black Sea and Kastamonu regions.

Tırnak kemane which is known as a wedding, dance and entertainment instrument locally in Kastamonu and 
around was at the back of its region with the same period of kemençe by type and performing, and keeps its place today too. But it is known Yörük kemane was played by Turkmen / Yoruk tribes and continued its usage by decreasingly until 1990's so it was removed of plating except the local regions (Figure 5). Instrument became integrated with the migratory identity of society and removed of playing when the migratory life replaced with settled life. This situation was the indicator that instrument was at the back of minds this identity.
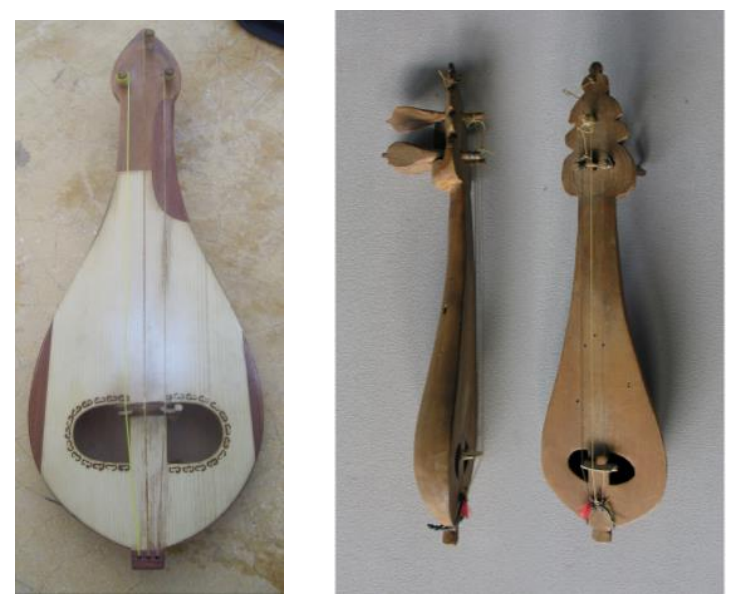

Fig 5.Tırnak kemane made by Mehmet Çelikel from Kastamonu and Yörük kemane from collection of Güner Özkan

\section{ACKNOWLEDGEMENT}

Consequently while pear shaped stringed instrument is played in different names in different regions it is played by a specific name and performing which is for that region. Determination of some instrument was settled in the memories of societies with example of kemençe and being significant characteristics of geographical social memory will probably create the need of detailed research of instrument types and curl movements. These examples are the significant indicator how social memory depends to shapes.

\section{REFERENCE LIST}

Baines, Antony, (1992). The Oxford Companion to Musical Instruments, London: Oxford University Press.

Downie, Margret, (1981). The Rebec: an Orthographic and Iconographic Study", Ph.D. Dissertation, Virginia Morgantown: West Virginia University.

Farmer, Henry George, (1925). Byzantine Musical Instruments in the Ninth Century, Journal of the Royal Asiatic Society, April, (299-304).

Hızır Ağa, (1749). Tefhîm-ül Makâmât fî Tevlîd-in Nagamât, Topkapı Court Museum Library, no.1793.

İzbul, Yalçın, (1980). İşaret Bilimine Toplu Bakış, Genel Semioloji Kuramı, Journal of Hacettepe Beşeri Bilimler, 3, (52-71).

Remnant, Mary, (1968 - 1969). Rebec, Fiddle and Crowd in England, Proceedings of the Royal Musical Association, 95, (15-28).

Sachs, Curt, (1992). The History of Musical Instruments, New York: W.,W. Norton Company.

Saussure, Ferdinant, (1959). "A Course in General Linguistics", ed. Charles Bally and Albert Sechehaye in collaboration with Albert Reidlinger, trans. Wade Baskin, New York: Philosophical Society.

Butler, Paul. Private Collection.

Divic, Joseph.Private Collection. 